\title{
Overview of the Change in the Organization of the Education System in Gabon
}

\author{
MBA Eyeghe Jean Paulin ${ }^{1 *}$ \\ ${ }^{1}$ Ministry of National Education, Gabon \\ *Corresponding author: Ependja Towaka Antoine: aependja@gmail.com
}

Citation: Mba E. JP., (2021)

Overview of the Change in the Organization of the Education System in Gaboni. Open Science Journal 6(2)

Received: $2^{\text {nd }}$ November 2020

Accepted: $9^{\text {th }}$ December 2020

Published: $26^{\text {th }}$ May 2021

Copyright: (C) 2021 This is an open access article under the terms of the Creative Commons Attribution License, which permits unrestricted use, distribution, and reproduction in any medium, provided the original author and source are credited.

Funding: The author(s) received no specific funding for this work

Competing Interests: The author has declared that no competing interests exists.

\begin{abstract}
:
The question of change in the organization is at the heart of the concerns of public policy managers. This article proposes to analyze the management of organizations in the educational system in Gabon. We have examined what is said and what is best done in the field in an attempt to identify this consideration by the theorists of change. As pointed out by several authors, particularly those who have investigated this issue, change is a stakeholder in the management of organizations. At the end of this literature review, we found that Gabon is not the only country to be confronted with the problem of change management in its education system. In conducting an education reform, it must take into account the balance of power within the organization. In order for the organization to achieve its goal, communication must become a permanent feature of human resources management. Thus, changing the education system is a titanic but achievable undertaking. The competence of the managers, the piloting mode and the management of human resources are determining factors in the process of change.
\end{abstract}

Keywords: Reform, Education, Education system, Competence, Management, Gabon

\section{Introduction}

The issue of change in organizations is at the heart of the concerns of public policy managers.

As some authors who have investigated this issue point out, change is a key part of the management of organizations.

At present, education is viewed from a different perspective from that which had been at the origin of the various works in the early 1960s. The economics of 
education currently focuses on three main areas: the contribution of education to economic growth, individual demand for education and the links between education and the labor market, and the management of education systems.

This literature review falls within the field of the management of education systems, in an attempt to analyze the management of organizations in the education system in Gabon. To do so, we will first define the concepts of change and organization, then present this consideration and finally draw a conclusion on the basis of the meta-analysis.

\section{Conceptual clarification of change and organization}

In the opinion, for example, change is leaving a thing, a state. It is therefore the act of modifying something, as can be noted from what Autissier and Moutot (2012) report and define it in terms of a break between an obsolete existing and a future synonymous with progress. For this, change only exists through the dynamics of the individuals who implement it. It becomes a rupture in its functioning when the following elements are transformed: practices, working conditions, tools, organization, profession, strategy and culture (the value system).

However, understanding change according to Collerette, Delisle and Perron (2011) is an attempt to understand a complex set of phenomena, movements, among other movements, and it is in fact an attempt to explain a continuous process that lies at the center of organizations and that is difficult to stop and take a snapshot of. Knowing that the process of change is difficult to isolate as a social phenomenon, we must, however, act as if we have carried it out in order to highlight what characterizes it. From the point of view of these authors, any transition from one state to another, observable in the environment and which has a relatively sustainable character could be understood as a change.

By extension, their definition of organizational change, which we consider to be relevant, is to state that it is any relatively lasting change in a subsystem of the organization, provided that this change is observable by its members or the people who are related to this system.

Here we can see that the term change refers to an observable modification that has occurred in the social system. This leads us to note that the expression process of change refers to the different phases experienced by the social system that must integrate the change. The process therefore takes place at the level of the personal experience of those who are experiencing change and who are not its promoters.

Thus, following what Collerette, Delisle and Perron (2011) argue, we can admit that the change process refers to the different steps that will be taken to undertake, promote and implement a change in a system. Such an approach includes the various activities that will be carried out by change people to ensure that the change materializes in the organization. In this sense, we agree with these authors when they argue that the organization refers to any production system, in a given environment, bringing together two or more actors who must interact, guided by a formal mission to be accomplished, and whose coordination is carried out by one or more of the actors who explicitly play this role.

In education, change could take place in the areas of infrastructure for working conditions, institutional organization based on the organization chart of services, classroom practices, curricula, teaching approaches, evaluation, and tools 
such as personnel, heritage and student management. Making a change in the education system therefore means putting an entire system into action. This requires decision making and learning new ways of relating.

According to Crozier and Friedberg (1977), for change to take place, there must be the acquisition of new capacities, that is, new knowledge and new modes of relationship and functioning between people, because changing the balance of power is not enough. The members of an organization are quite willing to change, very much so. However, the successful implementation of change requires a number of decisions throughout the project that structure the design and conduct of the reform.

\section{About organizational change}

To examine change in organizations, we have drawn on the work of a number of authors who have dealt with change management, including d'Autissier (2007, 2012), Dupuy (2004), Perrenoud (1999), Crozier (1977), Maganga (2005, 2011, 2012), Bareil (2004), Kourilsky (2014), and Mintzerg (1998, 2000). In their work, these authors set the scene for debates that involve a range of actors in driving the reforms. An examination of the relationships that these actors develop with respect to change could certainly shed light on what this entails.

When we look at change in organizations, we see that it is debated because of its importance in the reforms. Indeed, the authors who have investigated this question maintain that change, seen as a rupture, contributes to the evolution of organizations in the responses that actors have given to provide solutions to the problems that block the functioning of these organizations. Moreover, taking up the clarification that Autissier and Moutot (2007), Collerette, Delisle and Perron (2011) make about change, we can retain that it is a rupture between an obsolete existing and a future synonymous with progress. For them, change only exists through the dynamics of the individuals who implement it, because it only becomes a rupture in its functioning when practices (ways of doing things), working conditions (material environment), tools (IT and management), organization (zones of power and functional delimitations), business (the organization's know-how), strategy (the collective goals pursued and envisaged) and culture (the value system) are transformed. Now, we know that in an organization like the Ministry of National Education, adherence to change requires that the actors involved agree to abandon what already exists in order to believe in the future.

But if we consider that an individual is trained throughout his life and that change is part of this training, we can agree with its authors, to emphasize that the fear of the future or of what we will find is no longer justified. Indeed, the existing is a little bit the routine piloting of our practice and the future is the hope of our evolution, our promotion, our improvement. From the point of view of these authors, the link between these two visions is the risk that we take to abandon routine in favor of an uncertain but potentially better future. It is with good reason that it is believed that the heads of schools, school districts and Academy Directors, pedagogical advisors and inspectors deserve special attention. They are, unlike ministerial cabinets and directorates general, very close to the daily lives of teachers and students, but remain executives whose position is both an asset and a handicap in innovation. 
These executives are an asset because they can legitimately take initiatives, embody a community, negotiate with central or local government. Following the same authors, we believe that these actors do indeed constitute active relays for reforms of the education system at the local level. The knowledge of action and innovation of this particular category of actors is more than decisive, especially since they are now in all countries, in search of a clearer identity and training commensurate with their new roles.

According to our interpretation of Perrenoud's (1999) remarks, these actors also form a handicap because the relationship to change of the actors involved cannot be merged with that of those who are at the base and for whom the ministerial department is an ecosystem. Thus, it is not surprising that one can witness the development of resistance, sometimes fierce, in the implementation of reforms. It is at this level that we agree with what this author says, when he maintains that a reform is a political act notwithstanding that its motives are economic, pedagogical or demographic. Hence his mistrust of those who believe that all reforms must succeed and that resistance is reprehensible. Like all public policies, a school reform, from his point of view, is a complex human enterprise. That such an undertaking does not automatically succeed is not strange because of its limited rationality. It can never be the subject of a total consensus on the goals and strategies for implementation. Hence the need to place it within a system of collective action that no one fully masters insofar as some believe that evolution is the result of the clash of multiple value systems and multiple logics of action, none of which can be imposed without sharing.

As a systemic phenomenon, change can be seen, according to Crozier (1977) and Maganga (2005, 2011, 2012), as the transformation of a field of action in order to find a model of regulation that integrates all contradictions, favourable power relations, relational cognitive capacities and sufficient models of government. For these authors, it is a stage in the process of human development, of a social organizational model because it is more rational, resulting from a struggle between different people.

Conducting a reform in the educational system suggests that attention should be paid to the organization itself, to the points of view of the actors involved in the change, and to the environment where the reform takes place. In this sense, one can agree with Autissier (2003), Perrenoud (1999), Crozier (1977) and Maganga (2005, 2011, 20012 ), who recognize that, even if a reform claims to be in the public good or general interest, it cannot be agreed upon unanimously. For, it necessarily has overt or covert opponents who, at one level or another, actively oppose it or practice passive resistance. This is why they suggest, when steering the reform in an organization such as the Ministry of National Education, to take into account the adhesion of actors at all levels to overcome resistance of all kinds, knowing that everyone must respect the decision of the majority.

It should also be noted that, in their majority, those who initiate the reforms are very impatient in their practices. They want to move forward and evaluate too quickly to brandish results that must be considered over the medium or long term. However, by hiding the reality of teachers' work, for example, there is a risk that management will be faced with actors who are insensitive to change. It is hardly surprising that teachers, students, pedagogical supervisors and school heads are indifferent to change in terms of content, teaching methods or evaluation, if the reforms are silent on these tensions or content themselves with professing an ideal. 
In the case of Gabon, teachers and students arbitrated pragmatically by distinguishing between what they were told to do and what they could and could do effectively.

We can therefore understand that resistance to change could be linked, among other things, to the strength of the opponents of the reform, the involvement of all the actors, the fact of moving forward or evaluating too quickly, the underestimation of the power of relay, the failure to take into account the reality of teachers' work, and the level of qualification of professionals. What about the impact of communication in change management?

\section{Organization and communication in education management}

When a complex organization such as the Ministry of National Education commits to reforming its system, it is therefore essential to institute a communication plan that will allow change to be accepted and reduce resistance. A viable communication plan must take into account the elements of interpretation of each one and define its purpose beforehand in order to reach and integrate all the actors.

Communication (documentation, posters, leaflets and brochures, websites and forums, conferences and meetings) is an essential step in change management. And this must be done according to the more or less collective nature of the target and the desired interactivity. For each identified population, the different tools above will be mobilized in order to achieve the right message, at the right time.

For example, according to Autissier and Moutot (2003), for changes to be welcomed smoothly by all employees, communication must be made an integrated ally in the team in charge of the project. This communication must support the various departments of the organization. In other words, during a reform in the Education sector, communication plays an advisory role. The tools chosen should depend on the type of messages and targets to respond to internal problems (risk of social movements, persistent rumors). Thanks to its communication plan, the steering team will choose the words, media and working methods that will make pedagogical supervisors, general directors, directors of academies, school heads, teachers, students and parents adhere to the project and defuse internal tensions.

Autissier, Vandaneon-Derumez and Vas (2011) discuss Educationcommunication and internal marketing for a successful communication style.

Education-communication could allow the Minister of National Education and his managers to meet all the actors (teachers, students, parents) to provide them with information about the change and work with them on the working methods impacted by this change.

Internal marketing enables communication to be deployed according to a logic based on the targets and groups previously identified. Whether it is through meetings, forums, written or oral communication, by participating in these spaces of expression, all the actors concerned by the change can both express their questions and obtain explanations.

A well-developed communication plan during the implementation of an education reform promotes a good appropriation of the change project in terms of objectives, means, action plans, monitoring methods and adherence to the 
messages. The role of a communication plan in the success of the change is clear if it is at the center of the reformers' concerns.

However, prior to change, can human resource management not be an obstacle to the implementation of a reform, particularly in education?

\section{Human resource management in the administration of the education system}

The Ministry of National Education has as its human resources, teachers, nonpermanent manpower, pedagogical advisors and inspectors, study leaders, department heads, directors, general directors, general inspectors, general secretaries, the Minister's office and the Minister himself. In this sense, the objective of human resource management at the Ministry of National Education is to mobilize all staff for more effective public action.

It is therefore, on the one hand, the human resources administration that deals with payroll, jurisdiction, etc., and on the other hand, the human resources administration that deals with the administration of the Ministry of Education. On the other hand, we are talking about human resources development, which is responsible for career management, skills management, recruitment and training. In short, human resources management is characterized by the participation of the staff in the management of the organization, the development of human capital by taking into account its social status, its participation in decisionmaking, its decisive role in productivity and quality of work as well as the development of its skills. In this regard, all the characteristics of human resources management at the Ministry of National Education must be taken into account to ensure that change and decision making proceed smoothly.

Following on from what has just been argued, Dupuy (2004), pursuing the questioning, shows that the change that leads the system to transform itself is a bit like the one that allows the rules of the human system to be questioned. According to him, change leads to a real transformation of organizations and human relations. This is why he remains cautious in stressing that change requires entering into relationships with others through dialogue, cooperation and sharing. Indeed, he continues, any change requires a reconstruction of the reality of the Ministry of National Education. Since reality is inseparable from the way we look at things, reframing could be the best technique for initiating conceptual or emotional change.

We understand, therefore, that change in an organization such as the educational system necessarily leads to changes in attitudes and behaviors that bring about profound transformation.

From this point of view, the management of human resources becomes a fundamental condition for initiating change. This is why Perrenoud (1999) suggests that when it comes to the question of change in organizations, the human dimension of the balance of power in the implementation of a reform should not be overlooked. The games around rationality and efficiency, which are constant in the functioning of any organization, intensify in periods of reform. Whether the changes are proposed spontaneously by the enlightened, modernist fraction of the organization or whether they respond to changes in the environment, demand, resources, and the law, there is always a problem of appropriation. 
For Perrenoud (1999), neither endogenous modernization nor survival reactions to ecosystem evolution are shared evidence. It is necessary to justify them, therefore to propose a new construction of the reality of the organization, its efficiency, its functioning and its environment. This is what he called a construction likely to legitimize the change whose necessity never imposes itself. Change is rarely automatic in organizations. For, it generally appears to be decided according to the representations, analyses and anticipations of the actors, within the framework of their ordinary functioning within the organization. This is why it is necessary to integrate in the change a central element in human resources management, i.e. the organizing power of the actors in the exercise of it.

\section{Conclusion}

At the end of this overview of the change in the organization of education, we looked back on the process of its realization. In this regard, we noted that Gabon is not the only country to be confronted with the issue of change management in its education system. The literature review allowed us to observe what is being done elsewhere in order to shed light on our understanding of such a situation. In order to do so, we defined the key concepts, particularly that of change and organization.

After review, it was retained that it is not as simple to carry out a reform in education because the implementation of change cannot be done without taking into account the balance of power within organizations. With regard to organization and communication, we noted that these two concepts were inseparable, i.e. they share common areas if we look at how they work. In order for the organization to achieve its goals, communication must be permanently established in the management of human resources, i.e. the staff as drivers of change. Following this review of the literature, we have concluded that changing the education system is a titanic but achievable undertaking. The competence of the managers, the steering mode and the management of human resources are determining factors in the conduct of change.

\section{References:}

Autissier D. et Moutot, J-M. (2007). Méthode de conduite du changement, Diagnostic Accompagnement - Pilotage, Ed: Dunod.

Autissier D., Moutot J.-M. (2003). La conduite du changement : changer de conduite Edition : DUNOD.

Autissier D., Vandangeon-Derumez I. et Vas A. (2012). Conduite du changement : concepts clés, 50 ans de pratiques issues des travaux des auteurs fondateurs, Ed : Dunod.

Bareil, C. (2004). Gérer le volet humain du changement. Montréal : Éditions Transcontinental.

Collerette, P., Delisle, G. et Perron, R. (2011). Le changement organisationnel. Théorie et pratique. Québec : Presses de l'Université du Québec.

Crozier, M. et Friedberg, E. (1977). L'acteur et le système .Paris : Seuil, coll. Points.

Dupuy, F. (2004), sociologie du changement pourquoi et comment changer les organisations. Paris : Éditions Dunod.

Kourilsky, F. (2014) Du désir au plaisir de changer Le coaching du changement. Collection Management/Leadership. Paris : Dunod.

Maganga, T. (2005). Management et gouvernance des universités en Afrique : points de vue des acteurs à propos des modes de fonctionnement de l'Université Omar Bongo et de l'Université des Sciences de la Santé au Gabon, Thèse de doctorat, Université Laval, Québec.

Maganga, T. (2011). « Le directeur d'école : Leader ou Manager ?», Colloque des directeurs d'école, 8, 9 et 10 juin 2011, Communication de Bengole, Cocobeach. 
Maganga, T. (2012). Explication du texte relatif à la Loi n²1/2011 du 14 février 2012 portant Orientation Générale de l'Éducation, de la Formation et de la Recherche », Colloque des directeurs d'école, 5 et 6 avril 2012, Communication de Donguila, Ntoum.

Mintzberg, H (1998). Structure et dynamique des organisations, traduction française de the structuring of organisation, 10 pages, consulté le 26 Mars 2013, [En ligne] http://www.fr/servlet/com.univ.colllaboratif.utils.lecturefichiergw?id-fiche.

Mintzberg, H. (2000) : Le management voyage au centre des organisations, éditions d'organisations, Paris.

Perrenoud P. (1999). Le pilotage négocié du changement dans les systèmes éducatifs, Faculté de psychologie et des sciences de l'éducation Université de Genève. 